\title{
Powering Ahead: The Reform of the Electricity Sector in Uganda
}

\author{
Joseph Mawejje $^{1}$, Ezra Munyambonera ${ }^{1} \&$ Lawrence Bategeka ${ }^{1}$ \\ ${ }^{1}$ Economic Policy Research Centre, Makerere University Campus, Kampala, Uganda \\ Correspondence: Joseph Mawejje, Economic Policy Research Centre, Makerere University Campus, Kampala, \\ Uganda. Tel: 256-414-541-023. E-mail: jmawejje@eprc.or.ug
}

Received: August 30, 2013 Accepted: October 23, 2013 Online Published: November 4, 2013

doi:10.5539/eer.v3n2p126 URL: http://dx.doi.org/10.5539/eer.v3n2p126

\begin{abstract}
Uganda is among the very few countries in Africa that have fully embraced reforms in the electricity sector. These reforms that included unbundling, privatization, and the creation of an independent regulator were intended to improve sector performance and efficiency. The key feature of Uganda's model is that it sought privatization in the form of concessions and encouraged competition in the form of independent power producers on long term contracts. By focusing on developments in the generation and distribution segments, this paper gives a recount of the reforms and evaluates the progress made. Despite the post reform crises that rocked the electricity sector in 2005-2006 and again in 2011-2012 occurrences of load shedding have reduced greatly; the crisis periods have been replaced by promising developments. This has been on account of additional generation capacity and the Umeme license review that set new operational targets in distribution. We argue that the renewed Government commitment in the sector is set to lead to improved sector performance. In addition we propose some policy and regulatory measures that could lead to further improvements in the sector.
\end{abstract}

Keywords: Uganda, electricity, reforms

\section{Introduction}

During the past three decades, many countries, including Uganda, have undertaken reforms in their electricity sectors. Such reforms mainly entailed the transfer of ownership from Government to the private sector and usually involved the unbundling of Government utilities into different business centers for generation, transmission and distribution. Such reforms were motivated by a quest for improved overall sector efficiency (World Bank, 1993).

In Uganda, just like in many other developing countries, the reforms were driven by the need to reduce sector dependence on Government subsidies and thus free resources for other critical development needs. In addition, the reforms were intended to attract private sector participation, accelerate developments in generation and to improve overall electrification coverage (Engurait, 2005).

During the period leading to the reforms, the Uganda electricity sector was faced with numerous challenges among which were excessive power outages, limited investments, and very high technical and non technical losses all of which made for poor commercial performance (UETCL, 2008). With advice and financial support from the International Monetary Fund and the World Bank, the Government undertook major institutional restructuring measures to address these challenges. It was then that a strategic decision was reached to split the vertically integrated Uganda Electricity Board into different commercial segments in distribution, transmission and generation with the private sector expected to lead investments in the sector.

It is against this background that this paper seeks to evaluate the progress with regard to the developments in the sector since the reforms. Specifically, we focus on developments in generation and distribution and argue that renewed Government commitment will be critical in firming the achievements in the sector. In addition, Government has to decidedly deal with corruption in the procurement processes that have in the past delayed project start-off. The rest of the paper is organized as follows: section two reviews the history of the electricity sector in Uganda; section three discusses the framework for electricity reforms; section four presents the data and methods; section five discusses the results; section six discusses the renewed Government commitment in the sector and lastly section seven provides the conclusions. 


\section{The Historical Context of Uganda's Electricity Sector}

The development of Uganda's electricity sector dates back to 1905 when Sir Winston Churchill identified the potential of the Nile for electricity generation. However, the plans for setting up the electricity sector were delayed due to the perceived lack of an effective market for electricity at the time (Gore, 2009). It was therefore not until 1936 that the development of the electricity sector in Uganda got some headway when the head of the Kenya based East African Power and Lighting Company (EAP \& L) and Governor Philip Mitchell held discussions about the opportunities for electricity generation and distribution in the Uganda protectorate. In the same year EAP\&L was awarded a license for thermal generation and distribution in three major towns of Uganda. Electricity services on a commercial basis started in 1938 in three towns of Kampala, Jinja, and Entebbe (Mwaura, 2012).

The period after the world war was characterized by great economic change and growth. The 1946 Uganda development plan had placed much emphasis on the development of the electricity sector to drive an export-oriented and agricultural-based industrial economy (Gore, 2009). The plan was to start on a large hydro-electricity project and the creation of a quasi-independent body to oversee developments in generation, transmission and distribution of electricity. Thus in 1948, the Uganda Electricity Board was created as a vertically integrated natural monopoly, initially with a vision to supply electricity to the wider East African region (World Bank, 2000).

The electricity sector in Uganda was planned around exploiting the immense potential of the Nile. The prioritized dam projects were the Owen Falls Dam, the Bujagali falls and the Ripon falls. The Owen Falls project was deemed superior to the two other potential locations on technical grounds (Gore, 2009). The Owen Falls project started operations in December 1953 and was officially commissioned in April 1954, initially with a capacity of $150 \mathrm{MW}$ that was later expanded to $180 \mathrm{MW}$. It was widely expected that the electricity project would spur economic and social transformation. However, in the immediate years following the completion of the Owen falls dam the anticipated benefits were not realized because of the financial and technical constraints that faced the UEB (Gore, 2012). The major challenge that faced the UEB was the lack of finances required to expand the grid to the rural areas, with the result that new customer numbers flattened out quickly and that the sector relied heavily on Government subsidies (UNECA \& UNEP, 2007). Despite these challenges, the UEB set out on an ambitious plan to expand generation capacity. The Bujagali project was first proposed in 1957 and Government approval was eventually granted in 1965 (Gore, 2012).

The political unrest that followed the post-independence years, however, coupled with the waning interest from major project financiers, including the World Bank, meant that the project did not take off on time. What followed was a near collapse of the electricity sector in Uganda. The generation infrastructure was rundown, capacity fell to a mere $60 \mathrm{MW}$ and customer numbers fell by 25 percent (Engurait, 2005).

It was not until 1986 that interest in developing the Uganda electricity sector was re-awakened. In 1993, the Government of Uganda with the support of the World Bank under the public enterprise reform and divesture (PERD) programme undertook major reforms that led to the divesture of many public enterprises (Kuteesa et al., 2010). Many state-owned companies were put up for privatisation, but interestingly UEB was not initially among them (Tangri \& Mwenda, 2001). Six years later, the decision not to privatize the UEB would be reversed. A new legislation, the 1999 Electricity Act, was passed and this formed the basis for the unbundling of the monopoly into three separate segments for generation, transmission and distribution. While the generation and distribution segments have been opened to private sector participation, the transmission segment is still wholly Government owned.

\section{The Framework for Electricity Reforms}

Developing countries were encouraged to privatise their electricity sectors following earlier successes in countries such as Chile, Argentina, UK, Wales and Norway (Gratwick \& Eberhard, 2008). The early reformers were usually driven by the desire to embrace a more private sector led approach that would improve efficiency across the sector, through increased competition and regulation.

Such reformers followed a standard prescription that involved eight steps that were the recommended course of action for full liberalisation of the electricity markets. These steps as laid out by Gratwick and Eberhard (2008:3952) are as follows: corporatization - commercialisation - legislation - regulation - introduce Independent Power Producers - unbundle - divesture of generation and distribution assets and lastly - introduce competition. The reforms were usually promoted the World Bank and the International Monetary Fund and were geared towards attracting private sector investments. However, as Gratwick and Eberhard (2008:3957) point out, only a handful of countries have adopted the standard restructuring model of the electricity markets. Instead a new 
hybrid structure, which is characterised by dominant state-owned actor with the entry of IPPs permitted on the margins of the sector, is emerging.

The emergence of the hybrid model could be due to the mismatch between the agendas of the state and of the private companies. The mismatched agendas, among other factors, could have resulted into limited investments in generation and the limited willingness of private sector players to extend distribution lines to more distant and sparsely populated rural areas where costs and losses are higher (Pineau, 2002; Wamukonya, 2003). Thus what we see is a return to business by the state. In many countries therefore, the state still plays an active and significant role in the electricity markets.

\subsection{Overview of Uganda Electricity Reforms in Uganda}

The reforms in Uganda's electricity sector sought to make the sector commercially viable; reduce dependence on the Government Subsidies; improve access to electricity including rural electrification; improve reliability and quality of supply; attract private investors and finally take advantage of the regional markets (UNECA and UNEP, 2007). A series of events that included the development of a strategic plan that would provide the roadmap for sector transformation; and the introduction of a new legislation that provided for the creation of a sector regulator followed. All this was aimed at improving private sector participation that would enable increased supply of reasonably priced and reliable electricity (Karekezi et al., 2004).

The reforms necessitated the formulation of the Electricity Act which was passed in 1999 to provide for the legal and regulatory framework. In addition, the Rural Electrification Trust Fund was created to promote pro-poor electricity access. In 2001, the UEB was unbundled into three companies namely: the Uganda Electricity Generation Company Ltd (UEGCL); the Uganda Electricity Transmission Company Ltd (UETCL); and, the Uganda Electricity Distribution Company Ltd (UEDCL). The generation concession was awarded to Eskom Enterprises in 2002, while in May 2004 Umeme Ltd, the largest distribution company in Uganda, signed a 20 -year concession agreement to manage and operate the UEB distribution network. The transmission infrastructure remained Government owned.

The legal and regulatory framework for the Uganda energy sector was complimented by a policy framework that includes the energy policy, which was completed in 2002 and the renewable energy policy which was completed in 2007. Other organs such as the Electricity Disputes Tribunal, the Rural Electrification Agency (REA) and Board (REB) were established to provide guidelines for resolution of sector disputes, and promote, support and provide for rural electrification programs respectively.

When the reforms started being implemented only one hydro power plant at Nalubaale (180 MW) was generating electricity for the national grid (ERA \& MFPED, 2008). Subsequent efforts led to the completion of the 200 MW Kiira plant in 2003. In 2003 the assets of the two plants were leased out to Eskom Uganda Ltd, a subsidiary of Eskom South Africa, a public utility company. Two years later Eskom strengthened its stake in the Uganda electricity by assuming joint control of the distribution business with UK based Globeleq under the trading name Umeme. However in 2006 Eskom exited the distribution business and Globeleq assumed full control of Umeme. However, the sequencing of the reforms seemed to have been flawed; the sector was liberalized without a clear policy framework. The energy policy was approved three years after the Electricity Act in 2002 and the Renewable Energy Policy eight years later in 2007. Ideally, the law should follow policy such that the guidelines to regulate the sector are reflected in the policy.

\section{Data and Methods}

The data used in this study were sourced from three major sources: the electricity regulatory authority, the ministry of energy and mineral development (MEMD), and the Uganda bureau of statistics. Additional data was sourced through a comprehensive review of the literature. Data from the electricity regulatory authority (ERA) covers the time period 1990-2011, while data from the Uganda bureau of statistics is for the time periods 1992, 1999, 2002, 2006, and 2009 corresponding to the Uganda National Household Surveys. The data from the Uganda bureau of statistics helped us provide an in-depth analysis of electricity access and utilization, while data from the ERA and MEMD contained important variables used in this study that include: generation, demand, customer numbers, subsidies, losses, and price data. In addition, we used data from the literature. Specifically papers by Karekezi et al. (2004) and the United Nations Commission for Africa (2007) provided useful data particularly on the performance of the electricity sector before the reforms.

The data was analyzed using simple descriptive techniques as well a comprehensive review of the literature. This allowed us to assess the current status of the electricity sector against the reform objectives. Specifically, we investigated the outcomes of the reforms in two segments were competition was opened up, that is generation 
and distribution. In generation, we examine the growth in installed capacity and the events that led to the crisis that resulted into reduced generation capacity in 2006 and the subsequent corrective Government action and commitments. With regard to developments in distribution, we examine the entry of new distribution companies and their current capacities. In addition we investigated electricity access, customer growth, distribution efficiency and Umeme's sector investments.

\section{Results and Discussions}

\subsection{Developments in Generation}

Until 2005, hydro sources provided most of Uganda's electricity generation capacity. The joint capacity of the Nalubaale and Kiira dams was $380 \mathrm{MW}$ with the former contributing $180 \mathrm{MW}$ and the latter $200 \mathrm{MW}$. However, the actual combined output from the two dams was always below capacity. Therefore, following the liberalization of the electricity sector Government sought to attract private investments in generation to add to the existing capacity. Bujagali was the project of first priority. However, due to allegations of corruption in the procurement processes, negotiations with potential financiers that also included the World Bank became controversial and lengthy. These procurement challenges resulted into delayed project take-off and were partly the reason Uganda faced an energy crisis between 2005 and 2006. Details of the procurement and corruption challenges that also involved top Government officials and project contractors can be found in Kapika and Eberhard (2013) and Gore (2009). In addition some civil society groups expressed important environmental concerns that had to be dealt with before the project would continue. All these factors led to the delayed construction works of the Bujagali project.

In the meantime, actual electricity generation from both the Nalubaale and Kiira plants declined in 2006 as water levels in Lake Victoria dropped due to hydrological constraints in the Lake Victoria basin at the time (see Figure 1). The combined electricity generation from the two plants fell to about $140 \mathrm{MW}$ resulting in severe electricity deficits (Rugumayo, 2006).

The receding water levels (Figure 1) created so much debate (for details see Apunyo, 2007; Adam, 2006; Kull, 2006) and most of the analysis therein seemed to suggest that development of electricity projects on the Nile and the poorly conceived designs caused excessive water outflows from the Lake Victoria Basin with dire consequences for electricity generation. On Friday February 17, 2006 two civil society groups led by Lori Pottinger of International Rivers and Frank Muramuzi of the National Association of Professional Environmentalists (NAPE) wrote a letter to Mr. Gobind Nankani, the World Bank vice president for Africa (International Rivers, 2006). In the letter the World Bank, which provided financial support for the projects was requested to take full responsibility and institute adequate measure to address the issues at hand.

Such debates and actions by the civil society have been challenged by among others Tickodri-Togboa (2011) as misinformed and based on poor analysis. Moreover a paper by Yousef et al. (2000) provides a more plausible explanation to the receding water levels as the effects of the "Wolf-Gleissberg Solar Cycles". This paper was able to predict in 2000 that Lake Victoria water levels would recede in $2009 \pm 2-3$ years and goes ahead to predict similar expected occurrences in $2021 \pm 2-3$ and $2033 \pm 2-3$. Yousef et al. (2000:222) then suggested what would have been a solution that would have ensured sustained electricity generation thus:

"The problem of electricity production at drought conditions perhaps can be solved by an engineering technique that can use something like varying water level in two basins as in the Panama Canal."

However, such advice was not heeded. We therefore conclude that the crisis was due to poor planning and failure to use available knowledge and information. As a matter of fact by 2009 the combined available generation capacity for the two facilities was estimated to have risen to 175 MW (Kapika \& Eberhard, 2013), and has since risen again to averages of 200-250 $\mathrm{MW}^{1}$ suggesting that the problem was temporally. This however is not to discount the possible effects of human activity including the development of dams on the River Nile. 


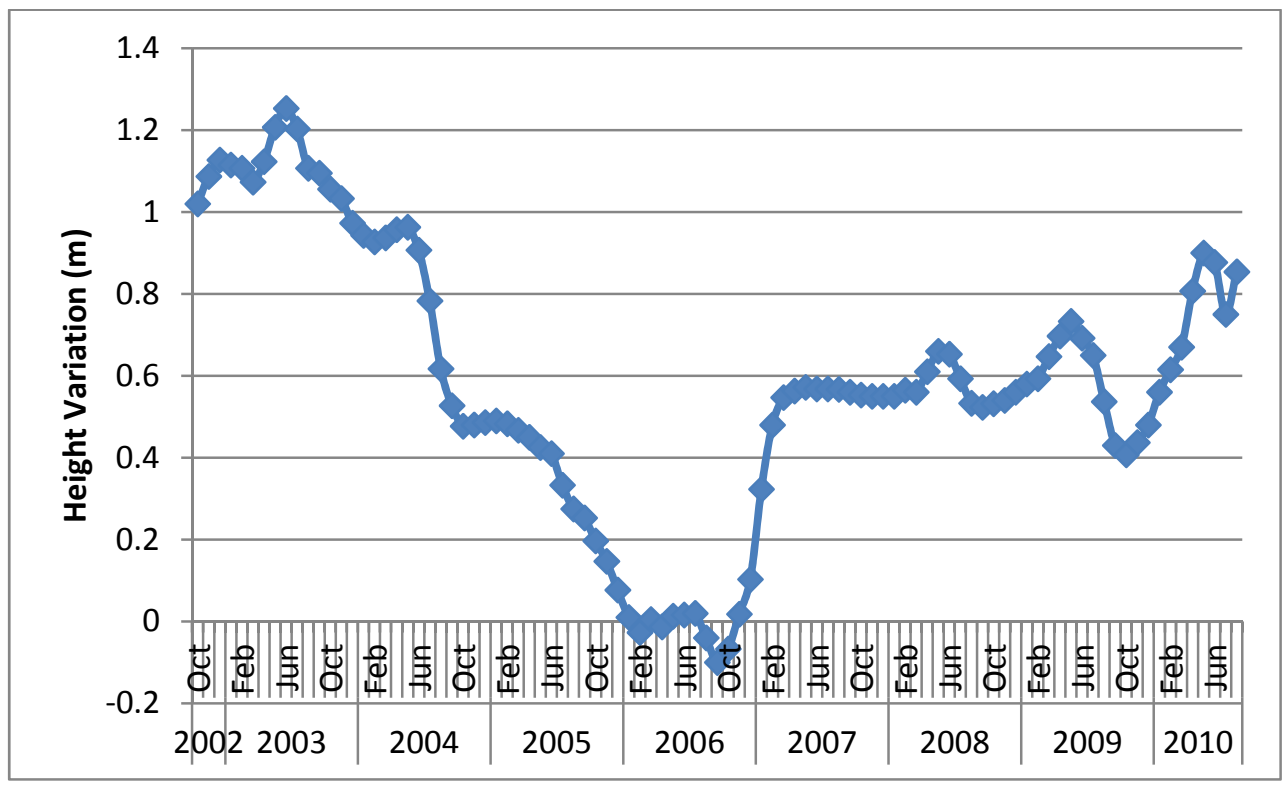

Figure 1. Lake Victoria height variation with respect to nine-year mean levels in meters
Source
of
data:
USDA
Foreign
Agricultural
Service,
at http://www.pecad.fas.usda.gov/lakes/images/lake0314.N.1.4.smooth.txt

The severe energy shortfalls that were occasioned by the constrained water levels led to massive electricity deficits (Figure 2). To mitigate the deficits in electricity supply, Government procured three thermal plants each with a capacity of $50 \mathrm{MW}$. Two of these plants were operated by Aggreko; one located at Mutundwe and the other at Lugogo and the other operated by Jacobsen (U) Ltd located at Namanve. In 2008 the Eletromaxx thermal plant located at Tororo provided a further $20 \mathrm{MW}$ bringing the total thermal capacity to $170 \mathrm{MW}$.

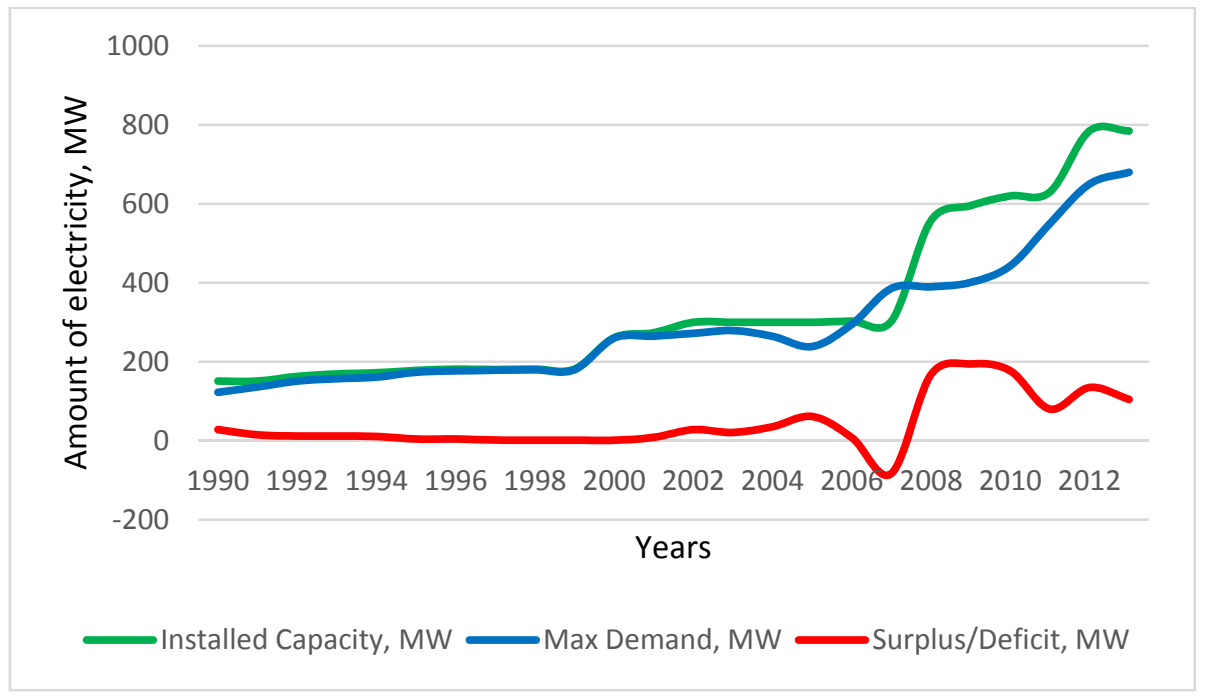

Figure 2. Installed capacity and demand

Sources of data: ERA, UBOS, MEMD.

The increased reliance on emergency thermal generation and its costly nature necessitated Government to increase subsidies to the sector so as to cushion the electricity consumer from the price increments. By 2011 the electricity subsidies had grown to UGX 447 billion, about 37 percent of the entire budget for the ministry of energy and mineral development (Electricity Regulatory Authority, 2011). By early 2010, thermal generation accounted for 41 percent of total generation up from 23 percent by 2006 (Table 2). By 2012 thermal costs 
accounted for 85 percent of total generation costs. The resultant effect was price increases of 35 percent and 41 percent in June and November 2006 respectively. However, the price increases were not sufficient to meet the financing gap. By 2010 the domestic electricity prices were UGX 385.6 per $\mathrm{kWh}$ against a cost reflective tariff of UGX 828 per kWh, the difference being met from Government budget by way of subsidies.

Table 1. Electricity subsidies, UShs, Billion

\begin{tabular}{ccccccc}
\hline & \multicolumn{7}{c}{ Years } \\
\cline { 2 - 7 } & 2006 & 2007 & 2008 & 2009 & 2010 & 2011 \\
\hline Subsidies in billion UGX & 107 & 78 & 169 & 229 & 351 & 447 \\
\hline
\end{tabular}

Source: Electricity Regulatory Authority.

The subsidies to the sector became unsustainable and in 2011 Government defaulted on its obligations to the thermal IPPs resulting in their temporary cessation of generation (Kapika \& Eberhard, 2013). The closure of some thermal plants were compounded by a fire at the Aggreko plant based at Mutundwe. The resultant massive electricity shortfalls had big implications for doing business in Uganda. Electricity rationing was started on a daily 12-hour schedule. At the peak of the crisis, a section of some Ugandan traders held massive demonstrations across the country protesting the expensive and usually unavailable electricity.

Table 2. Electricity generation mix

\begin{tabular}{ccccccc}
\hline \multirow{2}{*}{ Generation in GWh } & \multicolumn{7}{c}{ Time periods } \\
\cline { 2 - 7 } & 2006 & 2007 & 2008 & 2009 & 2010 & 2011 \\
\hline Hydro & 1,160 & 1,264 & 1,374 & 1,230 & 1,255 & 1,308 \\
Renewable & 79 & 91 & 132 & 171 & 209 & 347 \\
Thermal & 370 & 539 & 590 & 896 & 1022 & 1029 \\
Total Generated & 1,609 & 1,894 & 2,096 & 2,298 & 2,486 & 2,684 \\
\% thermal in total generated & 23 & 29 & 28 & 39 & 41 & 38 \\
\hline
\end{tabular}

Source: Electricity Regulatory Authority.

The completion of the $250 \mathrm{MW}$ Bujagali plant, the $9.5 \mathrm{MW}$ plant at Buseruka and the $3.5 \mathrm{MW}$ plant at Nyagak has provided great reprieve to the Uganda electricity sector and for the first time in over three decades Uganda has enough electricity to satisfy peak demand. This has led to the decommissioning of two of the thermal plants. In addition the 1.7 MW bagasse co-generation project at Lugazi Sugar Cooperation of Uganda Limited (SCOUL) was completed raising total installed capacity from about 540 MW in 2005 to 800 MW by March 2013.

In January 2012, with a view of using the scarce available resources to secure future electricity generation and supply, Government scrapped all subsidies to the electricity sector. Generation projects such as Karuma and Ayago (both $600 \mathrm{MW}$ ) have been earmarked for immediate construction. 
Table 3. Installed electricity capacity in MW 2008-2013

\begin{tabular}{|c|c|c|c|c|c|c|}
\hline Plant Name & 2008 & 2009 & 2010 & 2011 & 2012 & 2013 \\
\hline \multicolumn{7}{|l|}{ Hydro Electricity } \\
\hline Nalubale & 180 & 180 & 180 & 180 & 180 & 180 \\
\hline Kiira & 200 & 200 & 200 & 200 & 200 & 200 \\
\hline Kasese Cobalt Company Ltd & 10 & 10 & 10 & 10 & 10 & 10 \\
\hline Kilembe Mines & 5.4 & 5.4 & 5.4 & 5.4 & 5.4 & 5.4 \\
\hline Bugoye Tronder & - & 13 & 13 & 13 & 13 & 13 \\
\hline Mpanga & - & - & 18 & 28 & 18 & 18 \\
\hline Ishasha & - & - & 6.5 & 6.5 & 6.5 & 6.5 \\
\hline Buseruka & - & - & - & - & 9.5 & 9.5 \\
\hline Bujagali & - & - & - & - & 250 & 250 \\
\hline Kisizi & 0.3 & 0.3 & 0.3 & 0.3 & 0.3 & 0.3 \\
\hline Nyagak & - & - & - & - & 3.5 & 3.5 \\
\hline \multicolumn{7}{|l|}{ Thermal Generation } \\
\hline Jacobsen Namanve & 50 & 50 & 50 & 50 & 50 & 50 \\
\hline Electromaxx Tororo & - & 20 & 20 & 20 & 20 & 20 \\
\hline Aggreko Kiira & 50 & 50 & 50 & 50 & - & - \\
\hline Aggreko Mutundwe & 50 & 50 & 50 & 50 & - & - \\
\hline \multicolumn{7}{|l|}{ Bagasse cogeneration } \\
\hline Kakira sugar works & 12 & 12 & 12 & 12 & 12 & 12 \\
\hline Kinyara Sugar works & - & 5 & 5 & 5 & 5 & 5 \\
\hline Lugazi SCOUL & - & - & - & - & 1.7 & 1.7 \\
\hline
\end{tabular}

Source: Electricity Regulatory Authority and Uganda Bureau of Statistics.

In addition to the operational electricity projects highlighted above, the Government has earmarked the following projects as priority for development in the near future: Karuma, $600 \mathrm{MW}$; Isimba, $188 \mathrm{MW}$; and Ayago, 600 MW. Other potential projects include Ariang $400 \mathrm{MW}$ and thermal generation from the oil refinery that is expected to start at $100 \mathrm{MW}$ but eventually increase to $700 \mathrm{MW}$.

\subsection{Developments in Distribution}

Following the reform process, the distribution network that belonged to UEB was concessioned to Umeme under a 20 -year lease contract. The state-owned UEDCL continues to own the distribution network at $33 \mathrm{kV}$ and below in the areas where UEB used to operate with a few additions made by REA and Umeme. Additional but smaller distributional companies include The West Nile Rural Electrification Company (WENRECO) and Ferdsult Engineering Services Ltd. In a bid to speed up rural electrification two cooperative societies namely; Pader Abim Energy Cooperative Society and Bundibugyo Energy Cooperative Society were granted licenses to distribute electricity in some of the most remote areas of Uganda. 
Table 4. Distribution companies in Uganda

\begin{tabular}{ll}
\hline \multicolumn{1}{c}{ Distribution company } & \multicolumn{1}{c}{ Status } \\
\hline Umeme & $\begin{array}{l}\text { Umeme inherited customers that were once served by UEB and was } \\
\text { leased the UEDCL assets under a } 20 \text { year concessional arrangement and } \\
\text { controls 97 percent of the districbution market in Uganda. Umeme had a } \\
\text { total of 5000,000 } 2012\end{array}$ \\
& $\begin{array}{l}\text { Ferdsult operates and maintains a rural electricity distribution network } \\
\text { concessionaire under a 10 year agreement with the Rural Eelectrification } \\
\text { Agency. Areas of operation include the districts of: Kibaale, Kyenjojo, } \\
\text { Rukungiri, Kanungu, Ntugamo, Isingiro, Rakai, and Masaka. Ferduslt } \\
\text { pioneered the pre-paid metering system in Uganda and currently serves } \\
\text { about 10,000 consumers. } \\
\text { WENRECO operates an off-grid distribution network in the }\end{array}$ \\
West Nile Electricity & $\begin{array}{l}\text { Northwestern districts of Arua, Paidha, Nebbi, Koboko, Maracha, } \\
\text { Zombo and Yumbe. The company operated the 3.5MW Nyagaka HPP } \\
\text { and served about 4000 customers by March 2013. }\end{array}$ \\
Company (WENRECO) & $\begin{array}{l}\text { BECS runs the distribution concessionaire in Bundibugyo district since } \\
\text { 2009. Accordingly, BECS took charge of electricity distribution, grid } \\
\text { maintenance and managing the revenue from power consumers. } \\
\text { Currently BECS serves about 1500 customers. }\end{array}$ \\
Coop. Society (BECS) & Serves about 1500 customers in Pader, Abim and Agago districts \\
Pader - Abim Energy & \\
cooperative & KIL runs a 10-year concessionaire to distribute and sell electricity in the \\
Kilembe Investments & $\begin{array}{l}\text { Districts of Kasese, Rubirizi and surrounding areas. The license runs for } \\
\text { ten years and is renewable. Currently KIL serves about 2000 customers } \\
\text { on the pre-payment system. KIL intends to introduce solar energy for } \\
\text { users in isolated areas. }\end{array}$ \\
Limited (KIL) & \\
\hline
\end{tabular}

\subsubsection{Electricity Access and Customer Growth}

With an energy consumption per capita level of $75 \mathrm{kWh}$ and electrification rates of 11 percent, Uganda has one of the lowest electricity penetration rates in Sub-Saharan Africa (GOU, 2010). The constraints to electrification have been identified as the slow pace of developments in generation, vandalism of distribution equipment, and the limited effective demand especially among the rural areas (Ezor, 2009). Another challenge is that of the long distances and sparsely populated rural areas make it unattractive for the profit minded private distribution companies and therefore electrification, especially in the rural areas has been slow (Pineau, 2002). In this paper we investigated the evolution of electricity access in Uganda since 1992 using the Uganda Bureau of Statistics (UBOS) Uganda National Household Survey (UNHS) data. Results indicate significant increment in electricity access, between 1992 and, with overall electricity access rates rising from 7 percent in 1992 to 11 percent in 2009 (Figure 3). 


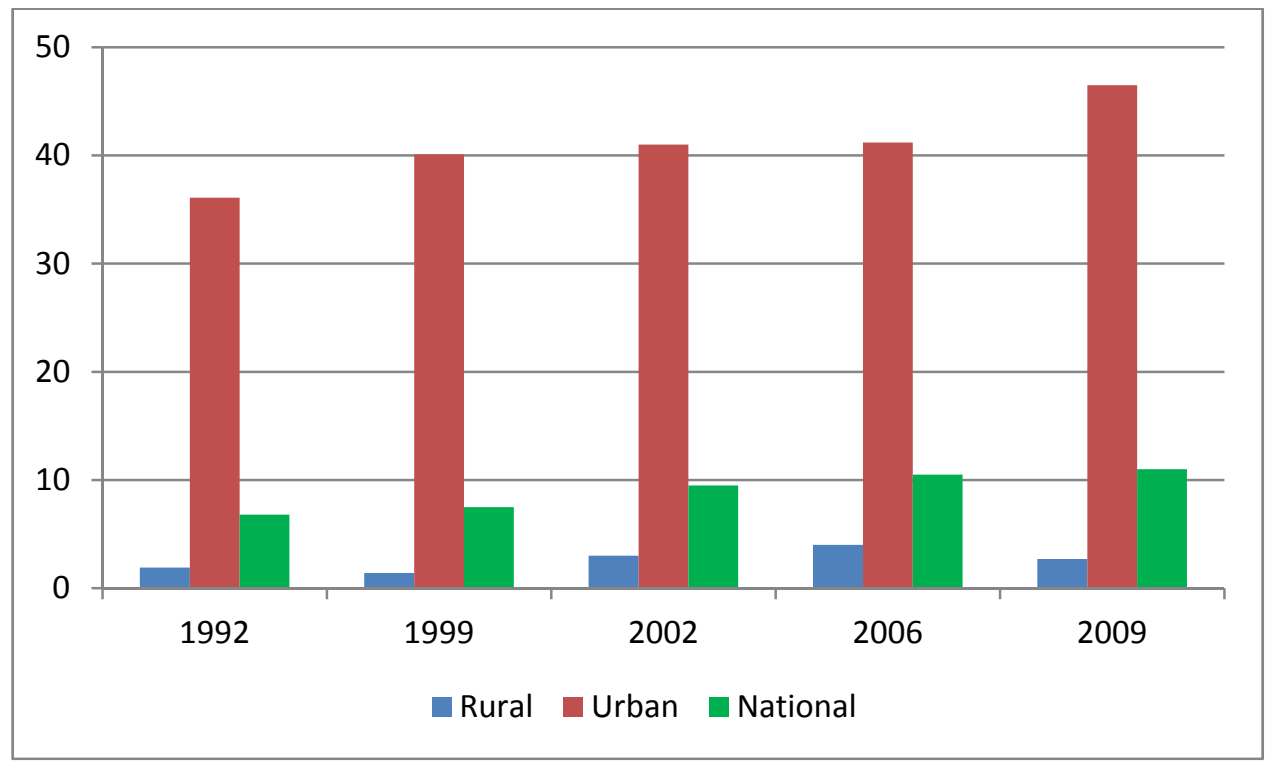

Figure 3. Electrification rates in Uganda, percentage

Source: Author Computations from UBOS UNHS data.

What we see is that electrification rates in Uganda are slowly growing. The completion of the Bujagali project and other priority projects is likely to spur further growth in access as is evidenced in the accelerated number of connections across all customer segments for Umeme, highlight the extent to which constrained electricity generation had suppressed demand as shown in Figure 4 below:

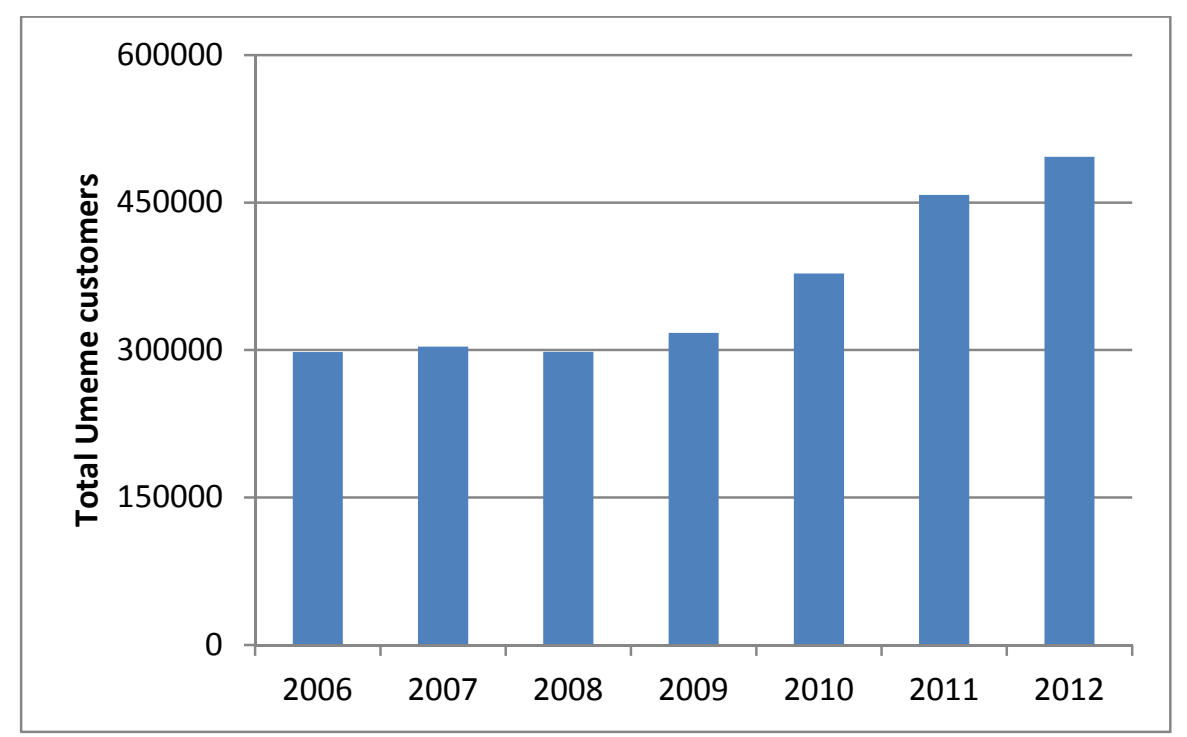

Figure 4. Umeme customers

Source: Electricity regulatory Authority.

\subsubsection{Distribution Efficiency}

Historically, the distribution losses have been very high in the 30-40 percent range, although they seem to have settled below the 35 percent mark from 2005. According to targets set in its concession agreement, the private distribution company was expected to reduce losses to about 30 percent by 2010 and to about 28 percent by 2011 . The distribution company has done well in reducing the losses from about 38 percent in 2002 to about 27 percent in 2012. In 2012 a review of the Umeme concession agreement was carried out by the Electricity Regulatory 
Authority and a loss reduction trajectory that will ensure distribution losses reduce to 13.25 percent by 2018 was agreed to. In addition quality of customer service has improved.

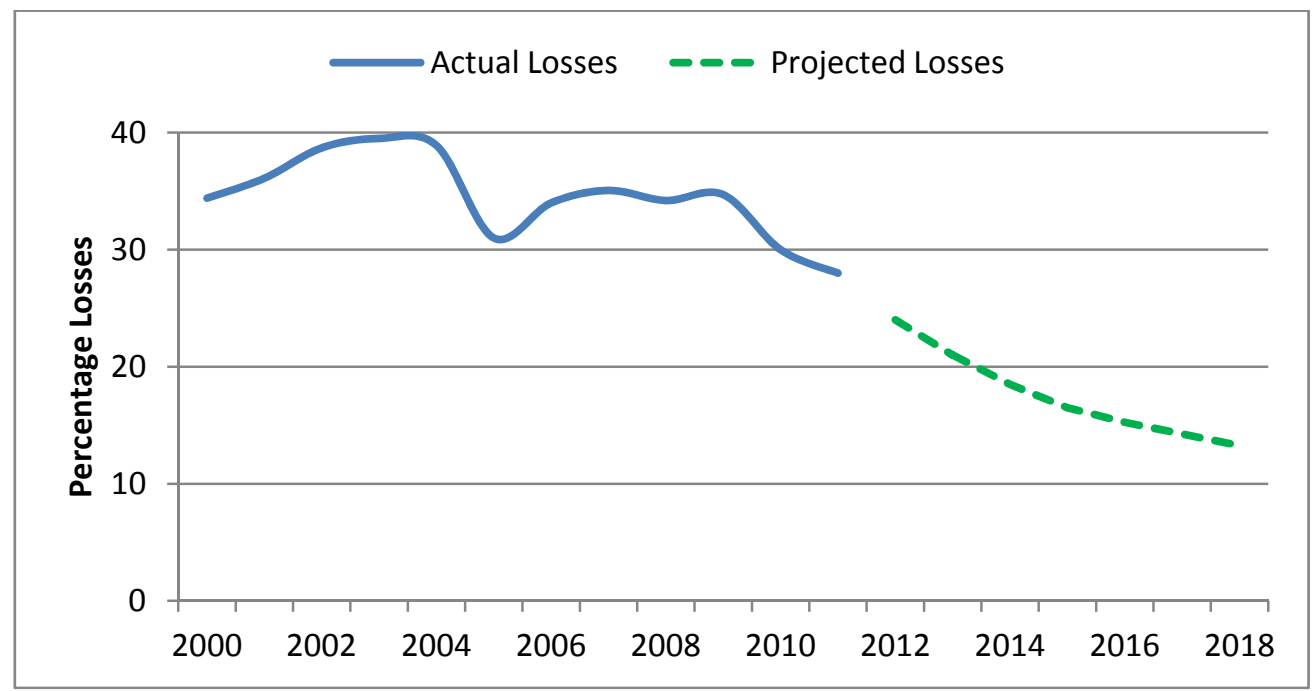

Figure 5. Electricity distribution efficiency

Source: Electricity Regulatory Authority.

In line with sector best practices, the distribution companies in Uganda have started rolling out pre-payment metering systems with a view of reducing electricity losses due to power theft and non-payment. Ferdsult and Wenreco have been running the pre-paid metering systems. Umeme Ltd started piloting the pre-paid meter system in 2012. All other smaller distributors use prepaid meters. It is expected that all electricity users in Uganda will have pre-paid meters within two years as a new measure to check power distribution losses due to electricity theft.

\subsubsection{Sector Investments}

The concession agreement between the Government of Uganda (UEDCL) and Umeme requires Umeme Ltd to have invested US\$65 million over a period covering the first five years of operation. By December 2011, Umeme had more than doubled the required target having invested US\$134 million (Umeme, 2012). In 2012 alone Umeme had invested over US\$36 million (UGX 93 billion) that was largely spent on new connections, feeders and electricity substations.

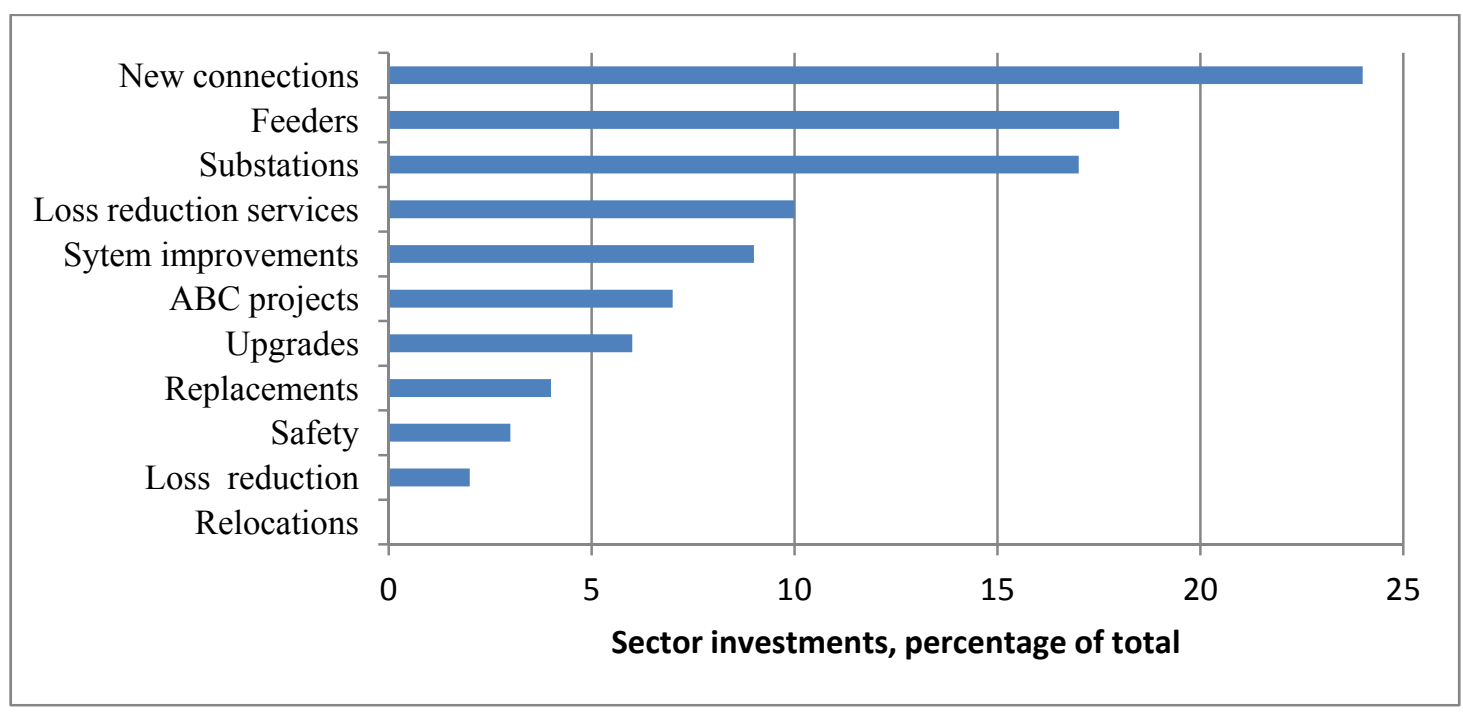

Figure 6. Distribution of 2012 Umeme sector investments 
Source: Electricity Regulatory Authority.

In November 2012, Umeme cross listed on the Uganda Stock Exchange (USE) thus tapping into a larger pool of resources. The IPO was expected to raise US\$69 million and part of this money intended to clear its shareholder loans so as to improve its balance sheet and attract more funding for investments in network expansion, upgrading and loss reduction.

\section{Renewed Government Commitment to the Sector}

Perhaps the most important factor in the development of the electricity sector in Uganda is the renewed commitment by Government. Following the challenges that led to the slow investments in the electricity sector, particularly in generation, and the crisis that befell the industry leading to massive blackouts in 2005-2006 and again in 2011-2012, the Government of Uganda decided to renew interest in the sector. Government policy is now focused on infrastructure development, especially in the provision of electricity and roads. This is highlighted in the five-year National Development Plan (NDP) that was completed in 2010 and the subsequent national budget speeches. Government's plan is to increase consumption per capita from $75 \mathrm{kWh}$ in 2010 to $3668 \mathrm{kWh}$ by 2040 and installed capacity from $425 \mathrm{MW}$ to $41,738 \mathrm{MW}$ under the same time period (GOU, 2010).

Table 5. Electricity generation and consumption projections

\begin{tabular}{cccccccc}
\hline Year & 2010 & 2015 & 2020 & 2025 & 2030 & 2035 & 2040 \\
\hline Capacity MW & 425 & 3,885 & 8,601 & 14,670 & 22,222 & 31,252 & 41,738 \\
Consumption (kWh/ capita) & 75 & 674 & 1,273 & 1,872 & 2,470 & 3,069 & 3,668 \\
\hline
\end{tabular}

Source: National Development Plan for Uganda.

After the completion and commissioning of the $250 \mathrm{MW}$ Bujagali plant, Government has expressed its commitment to provide partial funding the construction of the 600 MW Karuma plant without external help. Going forward Government has committed to take lead in future energy projects. To this effect the Government set up an energy fund through the Uganda Energy Credit Capitalization Company (UECC) that will provide financing for private sector energy investments especially for small projects with a capacity of up to $20 \mathrm{MW}$ and also to support rural electrification projects in Uganda.

Renewed Government commitment has also been expressed in the distribution segment. The new Rural Electrification Plan for the Period 2013-2022 will among others ensure that Government assumes "greater responsibility for planning, financing and overall management of the rural electrification sector" (GOU, 2013). The renewed interest in rural electrification has been occasioned by the reluctance of the major electricity distributor to extend electricity to rural areas.

\section{Conclusions}

Good progress has been achieved in Uganda's electricity sector, and this has been partly attributed to renewed Government interest in the sector. However, the electricity sector is still faced with some challenges especially in generation and distribution. In generation, there have been challenges of attracting private sector investments exacerbated by corruption in the procurement and tendering processes that have delayed project implementation. In distribution, the energy losses are still high and electrification is hampered by the reluctance of private profit-seeking companies to extend power lines to distant sparsely populated neighbor hoods.

To confront the challenges in generation Government has abolished subsidies in the sector with a view of prioritizing interventions that would secure future supply security. In distribution, the review of the distributor's license in 2012 has helped to set new operational targets that will result into a systematic loss reduction trajectory. The new rural electrification Plan for the Period 2013-2022 will ensure that among others Government assumes greater responsibility in pro-poor electrification. All these developments augur well for improved performance in the Uganda electricity sector. The post reform crises have been replaced by promising developments on account of improved Government involvement in the sector.

We make the point that this renewed Government commitment is set to lead to improved sector performance, especially in generation and distribution. Our arguments have important implications for Government policy. Specifically, the renewed Government commitment in the sector should be complimented by a renewed will to fight corruption that has affected project take-off and implementation in the past. In addition, the distribution 
companies should be supported with strong legal and regulatory framework that criminalizes electricity theft so as to reduce the non-technical losses due to electricity theft.

\section{References}

Adam, D. (2006). Uganda accused of 'pulling plug' on disappearing waters of Lake Victoria. The Guardian. Retrieved from http://www.guardian.co.uk/world/2006/feb/09/uganda.davidadam

Electricity Regulatory Authority. (2008). Constraints to Investment in Uganda's Electricity Generation Industry.

Electricity Regulatory Authority. (2011). Study on distribution system losses and collection rates by Umeme Ltd. Parsons Brinckerhoff Africa (PTY) Ltd (PB).

Engurait, S. P. (2005). Power sector reforms in Uganda: status and achievements. International Journal of Global Energy Issues, 23(2), 110-118. http://dx.doi.org/10.1504/IJGEI.2005.006873

Ezor, Z. (2009). Power to the people: rural electrification in Uganda. School for International Training. Retrieved from http://digitalcollections.sit.edu/cgi/viewcontent.cgi?article=1675\&context=isp_collection

Gore, C. (2009). Electricity and Privatisation in Uganda: The origins of the crisis and problems with the response. In McDonald David (Ed.), Electric Capitalism: Recolonising Africa on the Power Grid(pp. 359-399). HSRC Press, Capetown.

Government of Uganda. (2000). Rural electrification strategy and plan: covering the period 2001 to 2010. Ministry of Energy and Mineral Development.

Government of Uganda. (2012). Rural Electrification Strategy and Plan 2013-2022. Ministry of Energy and Mineral Development.

Gratwick, K. N., \& Eberhard, A. (2008). Demise of the standard model for power sector reform and the emergence of hybrid power markets. Energy Policy, 36, 3948-3960. http://dx.doi.org/10.1016/j.enpol.2008.07.021

International Rivers. (2006). Letter to the World Bank Regarding Owen Falls Dam and Lake Victoria. Retrieved from

http://www.internationalrivers.org/resources/letter-to-the-world-bank-regarding-owen-falls-dams-and-lakevictoria-3304

Kapika, J., \& Eberhand, A. (2013). Power sector reform and regulation in Africa: Lessons from Kenya, Tanzania, Uganda, Zambia, Namibia and Ghana. Human Sciences Research Council, Cape Town.

Karekezi, S., Kimani, J., Mutiga, A., \& Amenya, S. (2004). Energy Services for the Poor in Eastern Africa Sub Region: Energy Access Study of East Africa. Global Network on Energy for Sustainable Development, African Energy Research Network.

Kull, D. (2006). Connections between recent water level drops in Lake Victoria, Dam Operations and Drought. International Rivers. Retrieved from http://www.internationalrivers.org/files/attached-files/full_report_pdf.pdf

Kuteesa, F., Tumusiime-Mutebile, E., Whitworth, A., \& Williamson, T. (2010). Uganda's Economic Reforms: Insider Accounts. Oxford University Press.

Luyombo, S. N. (2008). The Transmitter. Uganda Electricity Transmission Company Limited (UETCL). Kampala.

Mwaura, F. M. (2012). Adopting electricity prepayment billing system to reduce non-technical losses in Uganda: Lessons from Rwanda. Utilities Policy, 23, 72-79. http://dx.doi.org/10.1016/j.jup.2012.05.004

Pineau, P. O. (2002). Electricity sector reform in Cameroon: is privatisation the solution? Energy Policy, 30, 999-1012. http://dx.doi.org/10.1016/S0301-4215(02)00054-X

Rugumayo, A. (2006). The Electricity Supply Situation in Uganda and Future Direction. Ministry of Energy and Mineral Development.

Tangri, R., \& Mwenda, A. (2001). Corruption and Cronyism in Uganda's Privatisation in the 1990's. African Affairs, 100, 117-133. http://dx.doi.org/10.1093/afraf/100.398.117

Tickodri-Togboa, S. S. (2011). On the contribution of Victoria Nile river discharge to the hydrological performance of East Africa's Lake Victoria. Second International Conference on Advances in Engineering and Technology. Retrieved from http://mak.ac.ug/documents/Makfiles/aet2011/Tickodri-Togboa.pdf 
Umeme. (2012). Annual Report $2012 . \quad$ Retrieved from http://umeme.co.ug/downloads/umeme_annual_report_2012.pdf

United Nations Economic Commission for Africa (UNECA) and United Nations Environmental Programme. (2007). Making Africa's Power Sector Sustainable: An Analysis of Power Sector Reforms in Africa. A Joint Report.

Wamukonya, N. (2003). Power sector reform in developing countries: mismatched agendas. Energy Policy, 31, 1273-1289. http://dx.doi.org/10.1016/S0301-4215(02)00187-8

World Bank. (1993). The World Bank's Role in the electric power sector. Retrieved from http://www-wds.worldbank.org/external/default/WDSContentServer/WDSP/IB/1999/09/17/000178830_98 101911183588/Rendered/PDF/multi_page.pdf

World Bank. (2000). Uganda Fourth Power Project. Retrieved from http://www-wds.worldbank.org/servlet/WDSContentServer/WDSP/IB/2000/07/07/000094946_0006290531 4733/Rendered/PDF/multi0page.pdf

Yousef, S. M., \& Amer, M. M. (2000, September). The sharp rise of Lake Victoria, a positive indicator to solar Wolf-Gleissberg cycles turning points. International Conference on the Environmental Hazards Mitigation. Conferences of Virtual Academia. Retrieved from www.virtuacademia.com/conferences

Apunyo, R. (2007, September). Dam Construction Flaws and the Receding Lake Victoria-Uganda. $10^{\text {th }}$ International River symposium and Environmental Flows Conference. Brisbane, Australia.

Government of Uganda. (2013). National Development Plan 2010/11 - 2014/15. National Planning Authority.

\section{Note}

Note 1. Electricity Regulatory Authority, personal communication.

\section{Copyrights}

Copyright for this article is retained by the author(s), with first publication rights granted to the journal.

This is an open-access article distributed under the terms and conditions of the Creative Commons Attribution license (http://creativecommons.org/licenses/by/3.0/). 